\title{
気流を伴う挿入管型消音器における共鳴音の卓越化について*
}

\author{
江崎孝志*1, 三上真 ${ }^{* 2}$, 小嶋直 哉*2
}

\section{Predominance of Resonance in Insert-Pipe-Type Muffler with Flow}

\author{
Takashi ESAKI*3, Masato MIKAMI and Naoya KOJIMA \\ ${ }^{* 3}$ Graduate School of Science and Engineering, Yamaguchi University, \\ 2-16-1 Tokiwadai, Ube-shi, Yamaguchi, 755-8611 Japan
}

\begin{abstract}
For insert-pipe-type mufflers with flow, the predominance of resonance in the flow-induced noise occured in particular combinations of muffler configuration and flow velocity as well as for simple expansion-cavity-type mufflers. The phenomenon is caused by a self-excited oscillation based on the feedback response from acoustic resonances of the muffler to the shear flow. Transitions from a tail pipe resonance to a cavity resonance and from a cavity resonance to a tail pipe resonance were also observed. This is called "resonance frequency transition". The coupled effect of the predominance of resonance and the frequency transition was investigated in the present research. For insert-pipetype mufflers, predominance of resonance occurred not only at tail pipe resonance frequencies but also at cavity resonance frequencies. Firstly, the frequency transition was demonstrated through the wave theory. Then, the predominance phenomena was expressed in a general way based on the wave theory and the feedback response from sound to flow.
\end{abstract}

Key Words: Noise, Aerodynamic Acoustics, Muffier, Predominance of Resonance, Self-Excited Oscillation, Wave Theory

\section{1. 暂 言}

気流を伴う消音器においては, 消音器という準閉 空間により内部の流れが複雑となり, さらに, 消音 器の空胴と尾管における音響特性が影響するため, 気流騒音の理論的な取り扱いが困難である. そのた め, 過去の研究においても実験的な手法により研究 が進められているのが現状である. 消音器から発生 する気流騒音と音響特性の関連については萩ら ${ }^{(1)}$,

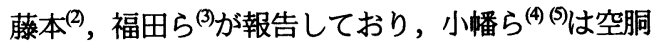
内の流れを可視化することにより，気流音の発生機 構について考察を行っている. また, 和泉らのは消 音器の気流音の低減について, 小嶋らのは気流音と 空胴内の速度変動の相関を使って気流音の発生場所 を特定する試みについてそれそれ報告している.ま た，森山らの(が尾管長を長くすることにより尾管 共鳴音を小さくさせ，空胴共鳴音について調査した 結果を報告している.

消音器における共鳴音の卓越化とは, 特定の消音 器形状とそのサイズ, 流速の組み合わせにおいて, 気流音圧レベルが大幅に増大する現象である.劉ら は単純空胴型消音器において空胴長, 尾管長, 流速

\footnotetext{
* 原稿受付 2003 年 2 月 21 日.

*1 正員, 山口大学大学院理工学研究科( - 755-8611 宇部市常 盤台 2-16-1).

*2 正員, 山口大学工学部.

E-mail : b2497@yamaguchi-u.ac.jp
}

を変化させた実験により，卓越化現象の発生状況， 発生機構を明らかにしている(19).この卓越化現象の 発生機構は, 消音器内で音響増幅された共鳴音によ り空胴入口部のせん断層が加振されて共鳴周波数と 等しい周波数の環状渦塊が発生し, それが尾管入口 部に衝突しさらに大きな共鳴音を発生させるという ものである.さらに, 劉らは尾管共鳴音の卓越化現 象についてのみ無次元数を提示して卓越化現象を統 一的に整理している(11).

気流を伴う消音器から発生する気流音の主成分は 尾管共鳴音と空胴共鳴音である. 挿入管型消音器に おいて挿入長を一定にして，空胴長を増加させると 尾管共鳴周波数は空胴共鳴周波数に, 空胴共鳴周波 数は尾管共鳴周波数に共鳴周波数が移行する．これ を共鳴周波数の移行現象と呼ふ(12).

本研究では, 気流を伴う挿入管型消音器において も共鳴音の卓越化か起こること, さらに共鳴周波数の 移行現象が起こることを確認した. そして, 共鳴音の 卓越化と共鳴周波数の移行現象の関連について調査し, 挿入管型消音器における卓越化現象の発生条件の予測 を行った.

\section{2. 实篗㨬是およひ方法}

供試消音器は軸対称の挿入管型消音器であり, ア クリル製である. その形状を図 1 に示す. 本実験では 空胴径 $D$ は $150 \mathrm{~mm}$ ，入口管径および尾管径 $d$ は $32 \mathrm{~mm}$ 


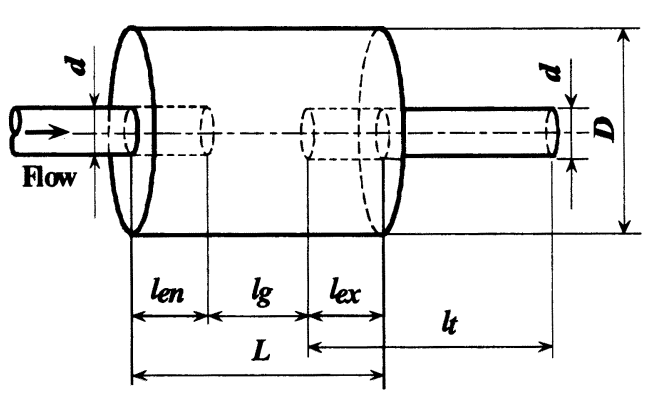

Fig1 Geometryof testmuffler

尾管長 はは $150 \mathrm{~mm}$ と固定し，間隙長 尾管入口との間隙長さ), 空胴入口挿入長 $b$ または空 胴出口挿入長 $b_{x}$ を変化させた. 消音器の空胴長 $L$ は空 胴入口挿入長 $l_{n}$ と間隙長 $l_{g}$ と空胴出口挿入長 $b_{x}$ の和 $\left(l=l_{a r}+l_{g}+b_{x}\right)$ である. また，本実験では主に空胴入口挿 入長 $b_{a}=30,90 \mathrm{~mm}$, 空胴出口挿入長 $b_{a}=0 \mathrm{~mm}$ の場合に間 隙長 $l$ を変化させた. 気流は, 送風機から内部吸音処 理したサージタンクを通し，さらに3段階に絞った後， 無響音室に設置した供試消音器に導入した. 消音器入 口管中心流速 $U$ は, 消音器空胴入口より上流 $1150 \mathrm{~mm}$ に設置したピト一管により測定した。本研究では $U=45 \mathrm{~ms}$ とした. 消音器出口から放射される気流音の 測定は, 消音器軸に対して $45^{\circ}$, 尾管端から $300 \mathrm{~mm}$ の位置を定点とし，その位置に設置したコンデンサマ イクロホンにより行った.この信号はデータレコーダ に記録後コンピュータ上での FFT 演算を含む信号処理 により解析した。

\section{3. 荑辁果}

\section{1 㨉入管型消音器における共腹音の特致}

空胴入口挿入長 管について, 気流音スペクトルから間隙長 伴う音圧レベル $L p$ および共鳴周波数 $F_{r}$ の変化を調べ た. 空胴入口挿入長 $b=30 \mathrm{~mm}$ の結果を図 2 に, 空胴入 口挿入長 $l=90 \mathrm{~mm}$ の結果を図3に示す. 図 2(a), 図3(a), では，各共鳴周波数 $F_{r}$ における音圧レベル $L p$ に加え， 音圧レベルのオーバーオール值 L $p$ も示した. また, 音圧レベルのピークを黒丸で示した. 空胴入口挿入長 の場合の全てにおいて, 特定の間隙長 しで音圧レベル Lpが増大する共鳴音の卓越化現象が起こっており， それによりオーバーオール值 $L p$ も皒越することがわ かる. また, 間尛長 しの増加に従い音圧レベル $L p$ の 卓越度合が小さくなることがわかる. 音圧レベル $L p$ に対応する周波数の図(b)を見ると，間隙長 しの増加に
対して共鳴周波数 $F_{r}$ が I-I ', II-II', III-III', …に沿 って増减する跳躍現象が起こっている.このように気 流を伴う系の代表周波数が系のある代表寸法の変化に ともない増減する跳躍現象は卓越化現象(9)や軸対称噴 流—リング系およひ值管系等(蛙の自励振動ループに 特有な現象である.

\section{2共啨周波数の移行現象}

図 2,3 の間隙長 $l_{g}$ に対する共鳴周波数において， 図中の丸(O)および及び三角 $(\Delta)$ は実測值 $F_{r}$ であり， 実線は空胴部分および尾管部分の共鳴周波数をそれ ぞれ独立に計算した尾管共鳴周波数 $f_{n}$ および空胴共 鳴周波数 $f_{r c}$ を示している.

尾管共鳴は, 尾管内の軸方向の音響固有モ一ドに よって励起される. 空胴共鳴は, 空胴内の軸方向お よび径方向の音響固有モ一ドのうち軸方向が強く励 起される. 尾管共鳴周波数 $f_{n}$ および空胴共鳴周波数 $f_{r}$ は下式から求められる ${ }^{(16)}$. 尾管共鳴周波数 $f_{n}$ は

$$
f_{r t}=\frac{c}{2\left(l_{t}+0.6 d\right)} \cdots \cdots \cdots
$$

となる. 空胴共鳴周波数 $f_{r}$ は

$$
f_{r c}=\frac{c}{2 L} \cdots \ldots \ldots(2)
$$

となる.ここで, $c$ は音速， $L$ は空胴長である. 間隙長 $l_{g}$ の増加に対して一定の ところが尾管共鳴周波数 $f_{n}$ を表し, 単調に減少して いるところは軸方向の空胴共鳴周波数 $f_{r}$ を表して いる.

図 2 の実測值については, 尾管共鳴周波数 $F_{n}$ の 1 次 成分である 1000 女付近の周波数は, 間隙長 l=120 の付近まではほほ一定となっているが, それ以降の間 隙長 しでは共鳴周波数 $F_{r}$ の低下が起きていることが分 かる. 一方, 間隙長 l=100mm において発生した 13001女 付近の空胴共鳴周波数 $F_{r}$ は低下をはじめ, 間 隙長 $l_{g}=160 \mathrm{~mm}$ 付近において, ほぼ尾管共鳴周波数 $F_{n}$ と一致していることがわかる.このように, 尾管共鳴 周波数 $F_{n}$ から空胴共鳴周波数 $F_{n}$, 空胴共鳴周波数 $F_{r}$ から尾管共鳴周波数 $F_{n}$ 个, 共鳴周波数 $F_{r}$ 力移行す 3. 図 3 の空胴入口挿入長 $b_{a}=90 \mathrm{~mm}$ においても同様に, 尾管共鳴周波数 $F_{n}$ 加空胴共鳴周波数 $F_{n}$, 空胴共 鳴周波数 $F_{n}$ から尾管共鳴周波数 $F_{n}$ 人, 共鳴周波数 $F_{r}$ が移行している. また図 2,3 において, 空胴部分お よび尾管部分の共鳴周波数をそれそれ独立に計算した 方法では実測值 $F_{r}$ と計算值 $f_{r}$ に差異か確認され, 共鳴 


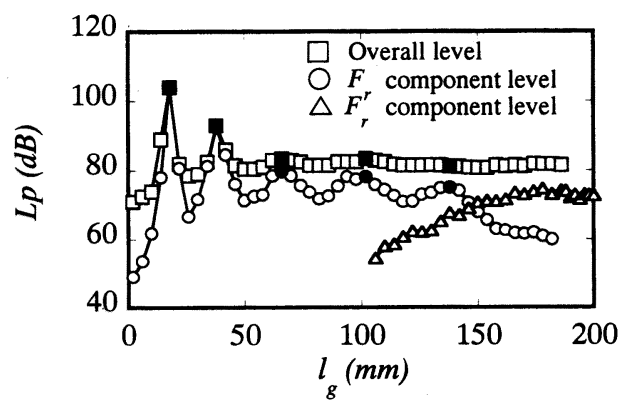

(a)Sound pressure level $L p$

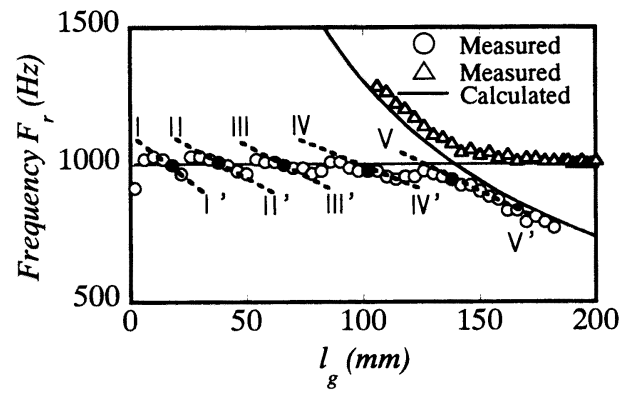

(b) Resonance frequency $F_{r}$

Fig2Sound pressure levels and resonance frequencies for $l_{a}=30 \mathrm{mmand} l_{c}=0 \mathrm{~mm}$

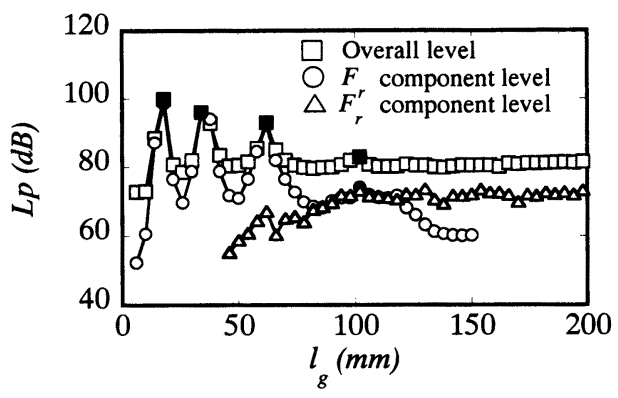

(a) Sound pressure level $L p$

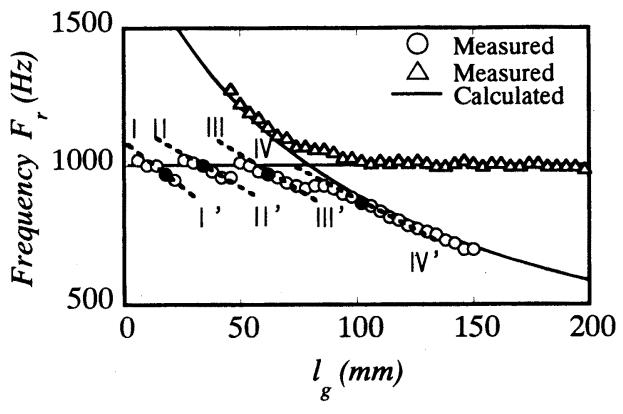

(b) Resomance frequency $F_{r}$

Fig3 Sound pressure levets and resonano frequencies for $l_{a r}=90 \mathrm{mmand} l_{a}=0 \mathrm{~mm}$

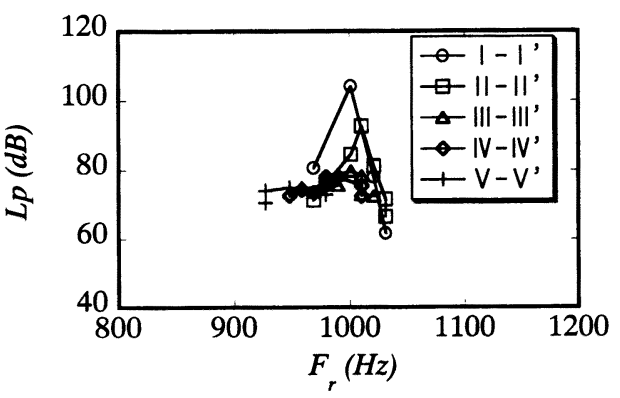

(a) $l_{a r}=30 \mathrm{~mm}$ and $l_{e}=0 \mathrm{~mm}$

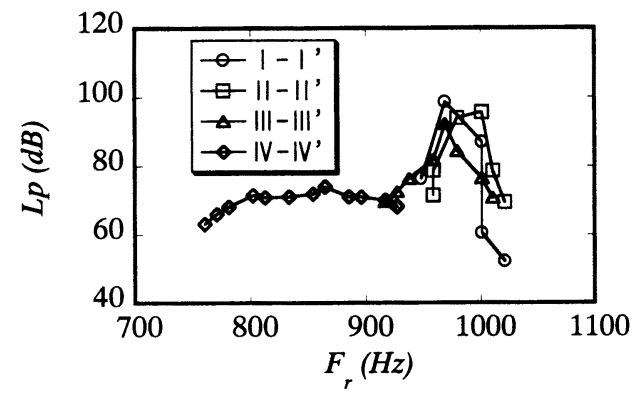

(b) $l_{e r}=90 \mathrm{~mm}$ and $l_{a}=0 \mathrm{~mm}$

Fig.4 Relation between sound pressure level $L p$ and resonance frequency $F_{r}$

周波数の移行現象が起こる周辺の，共鳴周波数を算 出できていないことが分かる．共鳴音の移行現象は, 尾管共鳴と空胴共鳴の音響的相互作用によって起こ る現象であると思われる。

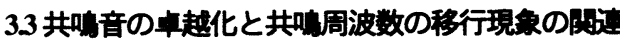

図 2, 3 において, I - I', II-II', III-III', ..に 沿って変化する共鳴周波数 $F_{r}$ を横軸とし, それそ れに対応する音圧レベル $L p$ を縦軸として図 4 に示 す.この図を基に，共鳴音の卓越化と共鳴周波数の 移行現象の関連について調べる. 図 4(a)の空胴入口 挿入長 $l_{e n}=30 \mathrm{~mm}$ については, 尾管共鳴周波数 $F_{n}=1000 \mathrm{~Hz}$ を中心とした周波数範囲で音圧レベル Lp の増加がみられる. すなわち，尾管共鳴音のみの卓 越化現象である。これは，図 2 からわかるように空 胴入口挿入長 $l_{a n}=30 \mathrm{~mm}$ では，尾管共鳴周波数 $F_{n}$ か ら空胴共鳴周波数 $F_{r}$ 入移行しない間隙長 $l_{g}$ で卓越 化現象が発生しているためである. 図 4(b)の空胴入 口挿入長 $l_{e n}=90 \mathrm{~mm}$ については, 尾管共鳴周波数 $F_{n}$ を中心とした周波数範囲で音圧レベル $L p$ の増加 ( I - I '〜III-III') と空胴共鳴周波数 $F_{r}$ 付近での音圧 レベル Lp の増加(IV-IV')の 2 種類が見られる.すな わち尾管共鳴音と空胴共鳴音の卓越化現象である. 
図 3 より空胴入口挿入長 $l_{a r}=90 \mathrm{~mm}$ では, 共鳴音が 尾管共鳴周波数 $F_{n}$ から空胴共鳴周波数 $F_{n}$ へ移行し た間隙長 $l_{g}$ でも卓越化現象が発生していると言える. 以上のことより，挿入管型消音器の卓越化現象の 予測には，尾管共鳴音のみでなく空胴共鳴音の考虑 も必要である. さらに, 消音器への流速や消音器の 幾何形状により共鳴周波数 $F_{r}$ の移行中に卓越化が 起こることも在りうる.よって, 共鳴周波数 $F_{r}$ が 移行する間隙長 $l_{g}$ での卓越化現象の予測を可能にす る必要がある。

\section{4 考察}

\section{1 掩入管型消音器における共们周波数の草出}

共鳴音の卓越化が発生するのは, 特定の位相基準を 満たす強い擋乱(環状渦塊)の発生周波数と消音器の共 鳴周波数が等しいときであると考えられている(1).し たがって，共鳴音の卓越化を予測するには，消音器の 共鳴周波数を把握する必要がある. 挿入管型消音器に おいては, 空胴部分および尾管部分の共鳴をそれそれれ 独立に計算した方法では, 共鳴音の移行現象が起こる 間隙長での共鳴周波数を正確に予測できない．そこで， 本研究では㨂入管出口から尾管出口までの間に平面波 理論(1)を適用し消音器の共鳴周波数 $f_{r}$ を算出した(付録 参照). その算出結果を図 5 に破線として示す. 空胴 入口挿入長 $l_{0}=30 \mathrm{~mm}$ および空胴入口挿入長 $l_{b}=90 \mathrm{~mm}$ に おいて, 実測值 $F_{r}$ と理論計算値 $f_{r}$ とがよい一致を示し ている. 尾管と空胴とを連成して共鳴周波数を計算す ることにより，移行現象も含む共鳴周波数を正確に計 算できることがわかる.

\section{2共虽音の主越化の予测}

共鳴音の卓越化が発生するのは特定の位相基準を 満たす強い擋乱(環状渦塊)が消音器内に平均 $n$ 個存 在しながら移流する際の発生周波数 $f_{e n}$ と消音器に おける共鳴周波数 $f_{r}$ が等しいとき

$$
f_{e n}=f_{r} \cdots \cdots \cdots(3)
$$

であると考えられている.ここで, 間隙長 $l_{g}$ の中に $n$ 個の渦塊が存在する場合の環状渦塊の発生周波数 $f_{e n}$ は, 文献 (11)にならい

$$
f_{e n}=\frac{n \alpha U}{l_{g}}(n=1,2,3, \ldots) \cdots \cdots(4)
$$

と表される.ここで $U$ は空胴入口管中心流速, dは無 次元移流速度である. $f_{e n}$ の間隙長依存性を図 6 に示す. 実線が環状渦塊の発生周波数 $f_{e n}$ を示し, 破線が消音器

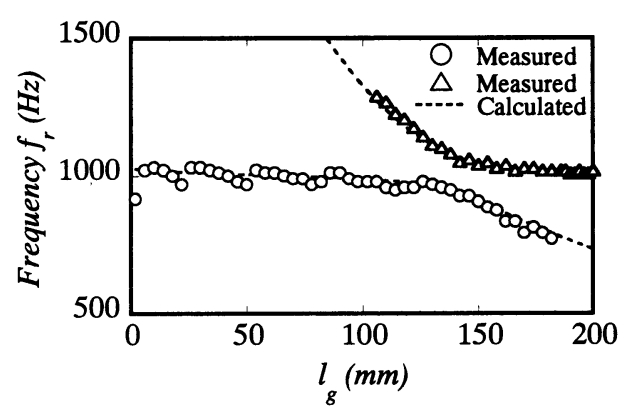

(a) $l_{c}=30 \mathrm{mmand} l_{a}=0 \mathrm{~mm}$

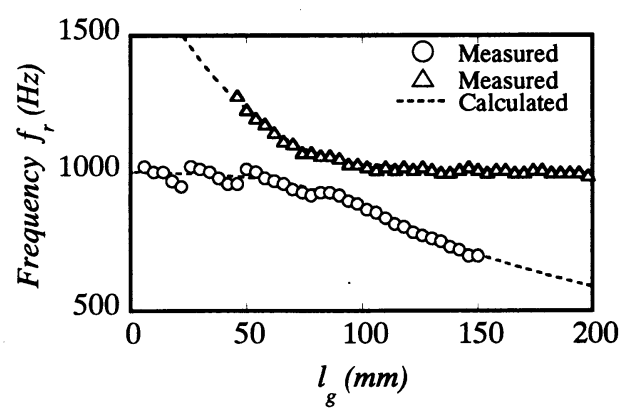

(b) $l_{b}=90 \mathrm{mmand} b_{a}=0 \mathrm{~mm}$

Fig5Estimation of frequency transition

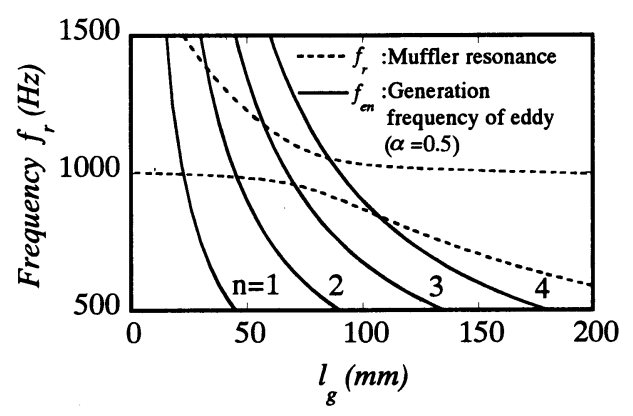

Fig6Estimation of predominanoe phenomena ( $\left.b_{a}=90 \mathrm{mmand} l_{a}=0 \mathrm{~mm}\right)$

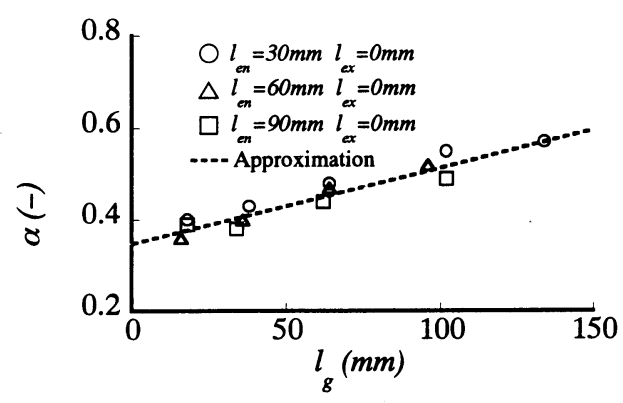

Fig7Dimensionlessconvective velocity $\alpha$ vs goplenghth $l_{g}$ 
の共鳴周波数 $f_{r}$ である. 図 6 においては実線と破線 の交点で式(3)の卓越化条件が成り立ち, 共鳴音の 卓越化が発生すると考えられる.ここでは, $f_{e n}$ を求 める際にの代表値として 0.5 を用いた. しかしのの 值は空胴長と共に増加する傾向があると報告(11)され ているため, 厳密には空胴長 $L$ または間隙長 $l_{g}$ と共 にのの值を変える必要がある. 検討する. 図 6 を見ると空胴共鳴音についても卓越 化が発生するところが, 数多く確認できる. 平面波 理論を用いて消音器の共鳴周波数 $f_{r}$ を算出すること により, 間隙長 $l_{g}=70 \mathrm{~mm} \sim 100 \mathrm{~mm}$ の共鳴音の移行現 象が起きる付近での卓越化現象の予測が可能となる.

\section{3 無次元移流速度 0 の间际長依存性}

環状渦塊の発生周波数の式(4)と実際に卓越化現象が 起きた周波数から, 間隙長 しにに対する移流速度のの変 化を調べた結果を図 7 に示す. 挿入長が変化しても移 流速度みは間隙長 しと共にほぼ直線的に増加すること がわかる. その原因は, 消音器は閉空間であり主流に 対して逆流を生じるためと思われる. 間隙長 しが短い と逆流の影響が大きいため渦塊の移流速度が主流速度 に対して遅くなる. 逆に間隙長 l功長いと逆流の影響 が小さいため渦塊の移流速度は主流速度に対してあま り遅くならないと考えられる. 以上のことより, 図 6 のように無次元移流速度 $\alpha$ を代表値として 05 を用い たのでは, 卓越化現象の発生予測の間隙長と実測の間 隙長に差異か顕著となる.

\section{4共喑の音越化の予测と実則の比较}

無次元移流速度 $\alpha$ 前の 4.3 節より, 間隙長 $l_{g}$ に 対して線形で変化する傾向があり, 卓越化現象を予 測する際にも間隙長依存性を考虑する必要があるこ とがわかった。そこで本節の卓越化現象予測の際に は, 図 7 に示される無次元移流速度 $\alpha$ の間隙長 $l_{g}$ ヘ の依存性を考虑する.

図 8は共鳴音の卓越化の発生予測と実測を比較し たものであり, 黒丸が害際に共鳴音の卓越化が発生 したときである. 尾管共鳴音およびそれから移行し た空胴共鳴音の卓越化は $f_{e n}$ と $f_{r}$ が一致したところに おいてほぼ起きており，平面波理論を適用すること により共鳴周波数の移行現象が起こる間隙長での卓 越化現象の予測が可能であることが示された. しか し, 空胴共鳴音の卓越化は図 6で予想されるほど起 きていない. その原因は，次節で検討する.

挿入管型消音器において，空胴部分および尾管部 分の共鳴をそれぞれ独立に計算する従来の方法では,

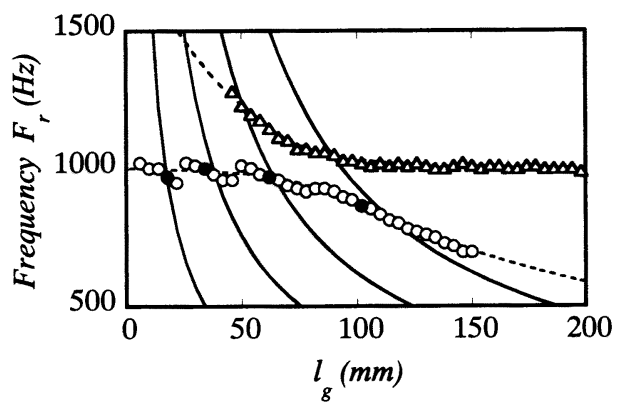

Fig.8 Comparison between estimation and measurement of predominance phenomena for $l_{e r}=90 \mathrm{~mm}$ and $l_{e r}=0 \mathrm{~mm}$

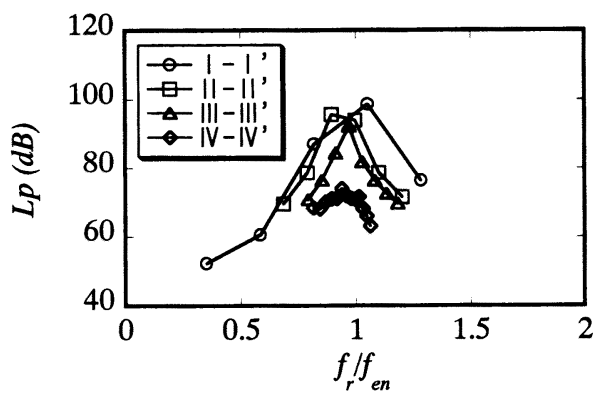

Fig.9 Relation between sound pressure level $L p$ and $f_{r} / f_{e n}$ ( $l_{e r}=90 \mathrm{~mm}$ and $\left.l_{e}=0 \mathrm{~mm}\right)$

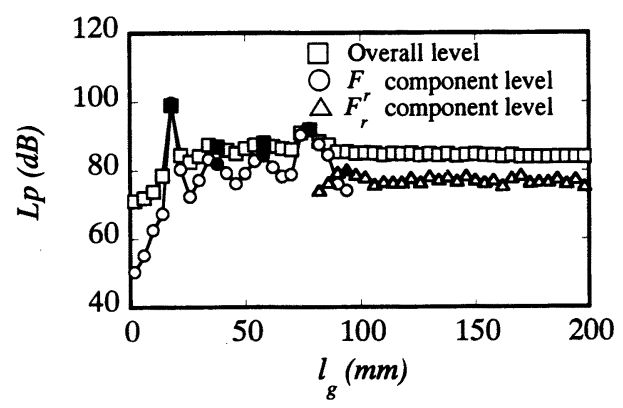

(a) Sound pressure level $L p$

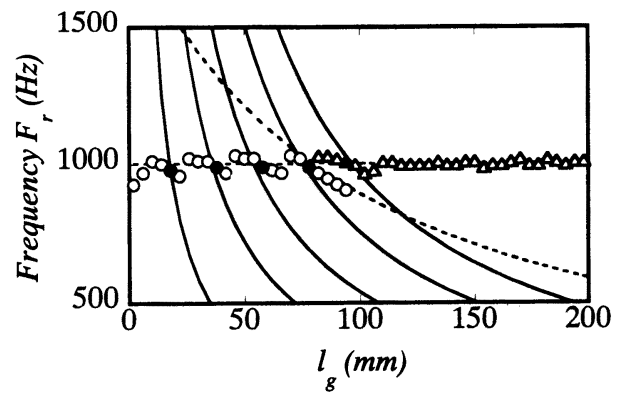

(b) Resonance frequency $F_{r}$

Fig.10 Sound pressure levels and resonance frequencies for $l_{e n}=0 \mathrm{~mm}$ and $l_{e x}=90 \mathrm{~mm}$ 
共鳴音の移行現象が起こる間隙長での実測の共鳴周 波数 $F_{r}$ を正確に予測できない.しかし, 4.1 節で示 したように平面波理論を適用することにより共鳴音 の移行現象が起こる間隙長を含んだ全ての間隙長で 共鳴周波数 $f_{r}$ を計算できた。 そこで図 4(b)において 横軸の消音器共鳴周波数の実測值 $F_{r}$ を計算値 $f_{r}$ で書 き直し,さらに環状渦塊の発生周波数 $f_{e n}$ で除して 無次元化したものを図 9 に示す. 無次元周波数 $f_{r} / f_{e r}=1$ 付近において音圧レベルが最も大きく, 共鳴 音の卓越化の発生は環状渦塊の発生周波数 $f_{e n}$ と消 音器の共鳴周波数 $f_{r}$ が等しいときであるという式(3) の理論が正しいことが示される. 前報(11)において行 った同様の整理方法は, 尾管共鳴音の卓越化現象に ついての統一化的整理であり, 尾管共鳴音のみの卓 越化現象の予測を可能にするものであった. しかし 本報告の結果は，尾管共鳴音にさらに空胴共鳴音も 含んだ無次元化による整理であり, 前報に比べより 一般性に優れた整理方法であると言える。

\section{5 流れによる音源位量と共喑の主越化の咸係}

前の 4.4 節において，尾管共鳴音の卓越化は図 6 での予想されるとおり起きているが, 空胴共鳴音の 卓越化は予想ほど起きていなかった。本節ではその 原因について, 消音器内の各位置での粒子速度の特 性と音源の関係から考察する. 尾管共鳴音の場合, 粒子速度は尾管入口において最大となり, しかもそ の場所に音源があるため尾管共鳴音の卓越化は予測 通り発生したと考えられる. 空胴共鳴音の場合, 粒 子速度の最大となる場所は空胴中央であり, 図 8 の 場合その場所に音源はないため, 空胴共鳴音の卓越 化は予測通り発生しなかった. 逆に言うと粒子速度 が最大の場所に音源があると空胴共鳴音においても 卓越化現象が起こると言える. 空胴共鳴において粒 子速度の最大となる場所である空胴中央に音源が存 在する条件は空胴入口挿入長 $l_{e r}=0 \mathrm{~mm}$ および空胴出 口挿入長 $l_{e}=90 \mathrm{~mm}$ および間隙長 $l_{g}=90 \mathrm{~mm}$ である. 空胴出口挿入長 $l_{a}=90 \mathrm{~mm}$ の挿入管について, 間隙 長 $l_{g}$ の変化に伴う音圧レベル $L p$ および共鳴周波数 $F_{r}$ の変化を図 10 示す. 共鳴周波数の図 10(b)には, 共鳴音の卓越化の発生予測に必要な消音器の共鳴周 波数 $f_{r}$ および環状渦塊の発生周波数 $f_{e n}$ の計算値も加 えている. 図 10(a)より予測通り間隙長 $l_{g}=90 \mathrm{~mm}$ 付 近において音圧レベル $L p$ が増大しており, それに 対応する周波数の図 10(b)では, 共鳴周波数 $F_{r}$ の跳 躍現象が見られ卓越化現象が起きていることがわか る. 以上の事より, 卓越化現象は粒子速度の最大位
置と各共鳴音の音源位置が一致する必要があること がわかった.

\section{5. 結}

挿入管型消音器から放射される気流音における共 鳴音の卓越化現象について, 挿入長と間隙長を変化 させて実験的に調べた. 平面波理論を用い卓越化現 象の発生条件の予測を行った. 主たる結論は以下の とおりである.

(1)気流を伴う挿入管型消音器においても, 共鳴音 の卓越化は起こる.

(2)挿入管型消音器においては, 空胴長を変化させ ると空胴共鳴周波数から尾管共鳴周波数へ, 尾管共 鳴周波数加空胴共鳴周波数へ共鳴周波数の移行現 象が起こる.

(3)共鳴周波数の移行現象の予測は, 消音器全体系 で音響特性を考え平面波理論を適用することにより 可能である.

(4)平面波理論により算出される消音器の共鳴周波 数と環状渦塊の発生周波数の関係式を用いることに より, 共鳴周波数の移行現象が起こる間隙長での卓 越化現象の予測が可能である.

(5) 卓越化現象は粒子速度の最大位置と各共鳴音の 音源位置が一致する場合に起こる。

\section{省文献}

(1)萩・村上, 機論, 37-301，(1971), 1679-1687

(2) 藤本, 音響学会誌, 27-11, (1971), 568-578

(3) 福田 - 小嶋 - 岩石, 機論, 48-432, B(1982), 1586-1594.

(4)小幡・平田, 騒音制御, 84, (1984), 49-53

(5) 小幡・平田, 騒音制御, 8-5, (1984), 44-49

(6) 和泉 - 小嶋 - 福田, 機論, 50-456, B(1984), 1879-1887

(7) 小嶋 - 中村 - 福田, 機論, 53-486, B(1982), 623628

(8) 森山・村上・萩, 機論, 53-495, B(1987), 33003308

(9) 森山・村上・萩, 機論, 58-546, B(1992), 594-601

(10) 劉 · 三上 - 小嶋, 機論, $62-600, \mathrm{~B}(1996), 3220-$ 3226

(11) 劉 · 岡 · 三上 - 小嶋, 機論, 63-611, B(1997), 2500-2506

(12) Liu,B., Kojima,N., Zhou,H.and Mikami,M., ASME Intemational Mechanical Engineering Congress \& Exposition, 95-WANCA-22, (1995) 
(13) 倉澤・小幡・平田・笠木, 機論, 53-488, B(1987), 1254-1261

(14) 倉澤・小幡・平田・笠木 - 山之上，機論，53494, B(1987), 3018-3026

(15) 小幡・倉澤・羽田, 機論, 61-583，B(1995), $890-896$

(16)伊藤, 音響工学原論, コロナ社, 171-175

(17) 福田基一・他，機械騒音ハンドブック，日本機 械学会, (1991), 493-498

\section{付 録}

\section{共四周波数の移行現象の予測}

共鳴音の移行現象を予測するには，尾管部および 空胴部という $2 つ$ 共鳴器でなく, 消音器全体を 1 つの共鳴器と考える必要がある. そこで, 消音器の 消音量を表す挿入損失 IIInsertion Loss)を用いて消音 器の共鳴周波数を求める.

\section{付 1.消音器における括入损失}

挿入損失 $\boldsymbol{L}$ は消音器を装着したときと各開口端 に対して消音器を装着しないときの同一測定位置で の音圧レベルの差で表され, 放射音のレベルとパワ 一をそれぞれ $L s[\mathrm{~dB}], P[\mathrm{~W}]$ とると次式で表される.

$$
I L=L_{s}^{\prime}-L_{s}=10 \log \frac{P^{\prime}}{P} \cdots \cdots \text { (5) }
$$

ここで, 添え字は消音器を装着しない場合を表す。 平面音波が消音器内を軸方向に直進する平面波理論 が成立ち, 消音器の有無により管端の環境が変わら ないとき $\mathbb{L}[\mathrm{dB}]$ は次式で表される.

$$
I L=20 \log \frac{U_{e x}^{\prime}}{U_{e x}} \ldots \ldots \ldots
$$

ここで， $U_{e x}$ は消音器出口端での体積速度を表す.

\section{付 2 四端子定数}

四端子定数は管路の入口と出口の音圧と体積速度 の関係を表すものである. 図 11 に示される管路系 において四端子定数を考える. 図 11 において消音 器をつけないときの管路の入口端と出口端の音圧と 別々に定義されている. 図 11 において入口管長お よび出口管長をそれぞれ $h, l$, 空胴入口部挿入長を $l_{e n}$, 空胴出口部挿入長を $l_{e x}$, 挿入管間隙長を $l_{g}$, 入 口管，出口管と空胴の断面積をそれぞれ， $s, S$ と

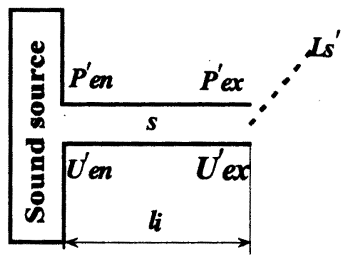

(a)Without the muffler

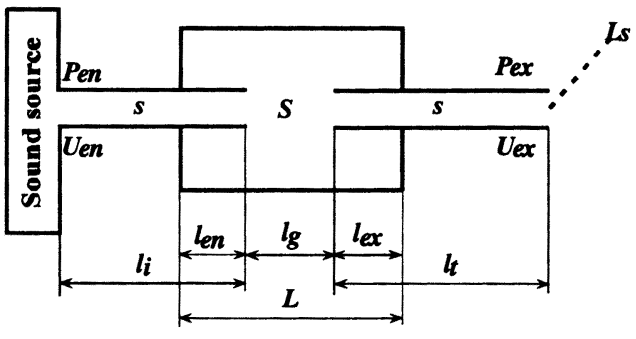

(b)With the muffler

Fig.11 Model of geometry muffler and four-terminal-constant

すると, 入口管部分 $l_{i}$, 間隙長部分 $l_{g}$, 尾管部分 $l$, での四端子定数は次のようになる.

$$
\left(\begin{array}{ll}
A_{x} & B_{x} \\
C_{x} & D_{x}
\end{array}\right)=\left(\begin{array}{cc}
\cos k l_{x} & j \frac{\rho c}{S_{x}} \sin k l_{x} \\
j \frac{S}{\rho c} \sin k l_{x} & \cos k l_{x}
\end{array}\right) \text { (7) }
$$

ここで, $x=i g, t$ である. また, 挿入部分 $l_{a n}, l_{\alpha}$ の四 端子定数は次式で表される.

$$
\begin{aligned}
& \left(\begin{array}{ll}
A_{y} & B_{y} \\
C_{y} & D_{y}
\end{array}\right)=\left(\begin{array}{cc}
j \frac{S-s}{\rho c} \tan k l_{y} & 1
\end{array}\right) \cdots(8)
\end{aligned}
$$

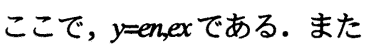

$$
\begin{aligned}
& k=2 \pi f / c
\end{aligned}
$$

であり,$f$ は周波数, $c$ は音速, $\rho$ は空気密度を表す. 消音器空胴内のどの位置でも平面音波が直進すると すれば, 消音器を付けないときの管路の四端子定数, 消音器を付けたときの消音器全体の四端子定数は, 四端子定数の従属接続の考え方により，以下のよう になる.

$$
\left(\begin{array}{ll}
A^{i} & B^{\prime} \\
C^{\prime} & D^{\prime}
\end{array}\right)=\left(\begin{array}{ll}
A_{i} & B_{i} \\
C_{i} & D_{i}
\end{array}\right) \cdots \cdots \cdot \ldots \cdot(9)
$$




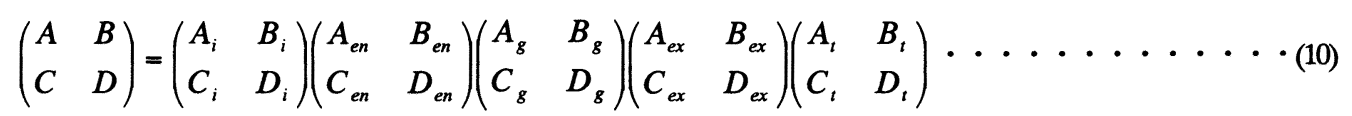

このときの $D, D^{\prime}, B, B^{\prime}$ 值は, 式(9)および式(10)を計算することにより以下のように求められる.

$$
\begin{aligned}
& D=\cos k l_{i} \cos k l_{g} \cos k l_{t}-\frac{s}{S} \sin k l_{i} \sin k l_{g} \cos k l_{t}-\sin k l_{i} \cos k l_{g} \sin k l_{t} \\
& -\frac{S}{S} \cos k l_{i} \sin k l_{g} \sin k l_{t}-\frac{S-s}{S} \cos k l_{i} \tan k l_{e n} \cos k l_{g} \sin k l_{t} \\
& +\frac{S-s}{S} \sin k l_{i} \sin k l_{g} \tan k l_{e x} \sin k l_{t}-\frac{S-s}{s} \cos k l_{i} \cos k l_{g} \tan k l_{e x} \sin k l_{t} \\
& -\frac{S-s}{S} \cos k l_{i} \tan k l_{e n} \sin k l_{g} \cos k l_{t}+\frac{(S-s)^{2}}{S s} \cos k l_{i} \tan k l_{e n} \sin k l_{g} \tan k l_{e x} \sin k l_{t} \cdots \cdots \\
& \begin{array}{l}
D^{\prime}=\cos k l_{i} \ldots \ldots \ldots \ldots \ldots \ldots \ldots \ldots \ldots \ldots \ldots \ldots \ldots \ldots \ldots \ldots \\
B=j \frac{\rho c}{s} \sin k l_{i} \cos k l_{g} \cos k l_{t}+j \frac{\rho c}{S} \cos k l_{i} \sin k l_{g} \cos k l_{t}+j \frac{\rho c}{s} \cos k l_{i} \cos k l_{g} \sin k l_{t}
\end{array} \\
& -j \frac{\rho c S}{s^{2}} \sin k l_{i} \sin k l_{g} \sin k l_{t}-j \frac{\rho c(S-s)}{s^{2}} \sin k l_{i} \tan k l_{e n} \cos k l_{g} \sin k l_{t} \\
& -j \frac{\rho c(S-s)}{S s} \sin k l_{i} \tan k l_{e n} \sin k l_{g} \cos k l_{t}+j \frac{\rho c(S-s)^{2}}{S s^{2}} \sin k l_{i} \tan k l_{e n} \sin k l_{g} \tan k l_{e x} \sin k l_{t} \\
& -j \frac{\rho c(S-s)}{S s} \cos k l_{i} \sin k l_{g} \tan k l_{e x} \sin k l_{t}-j \frac{\rho c(S-s)}{s^{2}} \sin k l_{i} \cos k l_{g} \tan k l_{e x} \sin k l_{t} \cdots \cdots( \\
& B^{\prime}=j \frac{\rho c}{s} \sin k l_{i}
\end{aligned}
$$

挿入損失 $\mathbb{I}$ は消音器の消音量を表すものであるか ら，挿入損失 $\mathbb{I}$ が正の值をとるときは消音を表し， 負の值をとるときは増音をあらわすため, 共鳴とは挿 入損失 $\mathbb{L}$ が負の無限大になる時である. そして $\mathbb{L}$ が 負の無限大になるには $D D D^{\prime}, B B B^{\prime}$ 限りなく 0 に近づ く必要がある. 本実験で用いた定常気流発生装置は消
音器の有無により音源の体積速度変化しないため, 定 速度音源とみなすことができる. すなわち $D D \prime=0$ と なることが共鳴を表していることになる. そこで， $D / D^{\prime}=0$ となる空胴長に対する周波数を計算した. この 計算結果が図 5 である. 図 5 に示す周波数は, 空胴部 において平面波理論が成立する周波数範囲である. 